\title{
Mycorrhizal Efficiency in Acerola Seedlings with Different Levels of Phosphorus
}

\author{
Elcio Liborio Balota*, Oswaldo Machineski and Neusa Maria Colauto Stenzel \\ Instituto Agronômico do Paraná (IAPAR), Caixa Postal 481, 86001-970 Londrina, Paraná, Brazil
}

\begin{abstract}
The objective of this work was to evaluate the response of acerola seedlings to arbuscular mycorrhizal fungi (AMF) with different levels of phosphorus $(P)$ additions. The experiment was carried out in greenhouse conditions, in a randomized factorial design with four treatments of AMF (control without AMF inoculation; Gigaspora margarita; Glomus manihotis; and Glomus clarum) and four phosphorus treatments (0, 30, 90, $270 \mathrm{mg} \mathrm{kg}^{-1}$ soil) in four replicates. The acerola plants were harvested after 120 days of the experiment. There were significant effects of arbuscular mycorrhizal fungi inoculation on the plant growth and nutrient contents in the plant shoots, mainly under lower P soil levels. Mycorrhizal plants presented a decrease of 55\% of manganese content in the shoot.
\end{abstract}

Key words: Malpighia emarginata D.C., mycorrhizal inoculation, plant growth, Mn toxicity alleviation

\section{INTRODUCTION}

The acerola crop (Malpighia emarginata A.D.) is typically a tropical fruit plant species originating from Central America and has spread to North and South America, including Brazil. In the last decades, it has received world-wide attention from the consumers, farmers, industries and exporters due to its high vitamin $\mathrm{C}$ content. The vitamin $\mathrm{C}$ concentration in the acerola fruits is a hundred times higher than that in orange juice. The acerola crop is well adapted to different soil conditions throughout the subtropical and tropical climates (Gonzaga Neto and Soares, 1994). However, there are few studies related to nutrition of acerola.

The arbuscular mycorrhizal fungi (AMF) form a symbiosis with the roots of more than $90 \%$ of the terrestrial plants, presenting great nutritional and ecological importance. This symbiosis is characterized by the bi-directional movement of nutrients, wherein fungi help the plants with the uptake of nutrients from the soil and the plant provides sugars to the fungi. One of the more pronounced beneficial effects of AMF is the enhanced development of host plants due to the increase in nutrient uptake, particularly nutrients that have low soil mobility and are present in low concentration in soil solution, which is made possible by their great amount of extra-radical hyphae. Those hyphae work as an extension of the root system, increasing the area of soil exploration by more than one hundred times, and thereby are responsible for up to $80 \%$ of the $\mathrm{P}$ absorbed by the plant (Marschener and Dell, 1994). The mycorrhizal symbioses can also enhance disease resistance and alleviate cultural as well as environmental stresses (Smith and Read, 1997).

Mycorrhizal symbiosis plays an important role mainly in the tropical soils, which normally have low $\mathrm{pH}$ levels, toxic levels of aluminum, and

\footnotetext{
*Author for correspondence: balota@iapar.br
} 
limited available phosphorus, due to its high phosphate-fixing capacity.

The majority of crops that are initially prepared in the nursery and then transplanted to the field present a variable degree of plant failure. Therefore, AMF inoculation can be an important practice in these crops, which pass through the nursery phase, particularly disinfected substrate is used, aiming at the elimination of pathogenic agents in the seedlings. Under these conditions, AMF may contribute to using smaller amounts of fertilizer, the better development and nutrition of the plants, the abbreviation of the transplant time to the field and the increased survival of seedlings in the field (Saggin Júnior and Siqueira, 1996).

The effect of mycorrhizae in increasing the growth of the plant has been well documented by several workers for different crops (Saggin Junior and Siqueira, 1996; Balota et al., 1997; Nogueira and Cardoso, 2003; Costa et al., 2005). Although there are few studies on the acerola crop, it has been observed that acerola seedlings show higher growth due to mycorrhizal symbiosis (Chu, 1993; Costa et al., 2001). However, in these studies, the authors had not used different levels of soil $\mathrm{P}$.

The objective of this study was to evaluate the effect of arbuscular mycorrhizal fungi on acerola seedling growth under different phosphorus levels.

\section{MATERIALS AND METHODS}

The experiment was carried out under greenhouse conditions with pots containing four $\mathrm{kg}$ of sandy soil. The soil used as substrate was a Latossolo Vermelho distrófico (LVd) according to Brazilian classification (Bhering and Santos, 2008), with the following chemical characteristics: $\mathrm{pH}$ in $\mathrm{CaCl}_{2}=$ 5.2; $\mathrm{P}$ in Mehlich solution $=5.5 \mathrm{mg} \mathrm{kg}^{-1} ; \mathrm{Ca}, \mathrm{Mg}$ and $\mathrm{Al}$ extracted with $\mathrm{KCl}$, and $\mathrm{K}$ in Mehlich solution equals to $1.45 ; 0.94 ; 0.00 ; 1.08 \mathrm{cmol} \mathrm{dm}^{-3}$, respectively; and $12.9 \mathrm{~g} \mathrm{dm}^{-3}$ of C. Dolomitic limestone was added to the soil to obtain $70 \%$ cation base saturation in the CEC and incubated for 60 days with moisture at field capacity. After the incubation, the soil $\mathrm{pH}$ was 6.4 , and the $\mathrm{P}$ content was $6.8 \mathrm{mg} \mathrm{kg}^{-1}$. The substrate was autoclaved twice at $121^{\circ} \mathrm{C}$ for one hour. After twenty days, the substrate was fertilized with $\mathrm{P}$ as triple superphosphate and milled to mix it completely with the substrate. The experiment was completely randomized, in a factorial arrangement, with the following treatments of AMF: control without AMF inoculation; Gigaspora margarita (Becker and Hall); Glomus manihotis (How., Siev and Schenck), Glomus clarum (Nicolson and Schenck) and four treatments of phosphorus addition $\left(0,30,90,270 \mathrm{mg} \mathrm{kg}\right.$ soil $\left.^{-1}\right)$ with four replicates. After the $\mathrm{P}$ addition the soil presented $18.6,43.2$ and $116.1 \mathrm{mg} \mathrm{kg}^{-1}$ of $\mathrm{P}$, respectively for addition of 30,90 and $270 \mathrm{mg} \mathrm{kg}^{-1}$ of $\mathrm{P}$. The $\mathrm{P}$ treatments were reported as P0, P30, P90 and P270. The seeds of acerola from different accessions of acerola Active Germplasm Bank at IAPAR were germinated in sterilized vermiculite. When the seedlings presented two pairs of leaves (about thirty days after germination), they were transplanted into the pots. Each pot received three seedlings, after twenty days, determined by selection, only leaving a plant per pot. The AMF inoculation (about 120 spores) was placed about 5 $\mathrm{cm}$ below the roots of the seedlings. The mycorrhizal inoculum was obtained from AMF IAPAR Collection using Brachiaria decumbens as the host plant. These mycorrhizal species were introduced in the AMF IAPAR Collection - in 1990. G. margarita and G. clarum were obtained from AMF UFLA (Federal University of Lavras) Collection, and had been isolated from coffee and corn crop, respectively. The origin of G. manihotis was Mycorrhizal CIAT Collection and it was isolated from cassava crop.

The experiment was conducted for 120 days and the following parameters were evaluated: number of leaves per plant, total leaf area per plant, leaf area per leaf and diameter of the stem. Leaf area was determined with an area meter (LI-3100C Area Meter). All soil and plant nutrient analyses were performed according to the Soil and Plant Analyses of IAPAR (Pavan et al., 1992). Manganese was extracted with $1 \mathrm{~mol} \mathrm{~L}^{-1} \mathrm{NH}_{4} \mathrm{AO}_{\mathrm{c}}$ $(\mathrm{pH}$ 7.0) solution at 1:10 soil-to-solution ratio, incubated with shaking for $6 \mathrm{~min}$, centrifuged at $2500 \mathrm{rpm}$ for $10 \mathrm{~min}$, and determined by ICP (Inductively Coupled Plasma). The mycorrhizal effectiveness (ME) was calculated based on the total leaf area per plant variable: $\mathrm{ME}=$ (total leaf area of the mycorrhizal plant - total leaf area of non-mycorrhizal plant) / total leaf area of nonmycorrhizal plant x 100 (Nogueira and Cardoso, 2007).

Results were submitted to the analysis of variance (ANOVA) test considering both AMF inoculation and $\mathrm{P}$ addition level factors. Averages were compared at a 5\% significance level using Tukey's test. Data for each AMF species were submitted to 
regression analysis with an increase of $\mathrm{P}$ addition. A significant equation by $\mathrm{F}$ test $(\mathrm{P} \leq 0.05)$ was chosen that presented a higher correlation coefficient $\left(R^{2}\right)$. All of the statistical analyses were performed using the SAS statistical package version 9 (SAS, 2002).

\section{RESULTS AND DISCUSSION}

The mycorrhizal plants and non-mycorrhizal plants showed interactions between the AMF x P doses with quadratic regression model due to the addition of $\mathrm{P}$ (Figures 1, 2 and 3). Mycorrhizal plants showed, in general, more rapid development than non-mycorrhizal plants. The mycorrhizal beneficial effect decreased with increasing $P$ levels. The AMF increased the number of leaves up to $247 \%$ in the treatment without addition of $\mathrm{P}$, $129 \%$ at $\mathrm{P} 30,27 \%$ at $\mathrm{P} 90$ and $9 \%$ at P270 (Figure 1-A). The diameter of stem increased up to $110 \%$ under the soil without $\mathrm{P}$ addition, $18 \%$ at $\mathrm{P} 30$, $15 \%$ at $\mathrm{P} 90$ and $14 \%$ at P270 (Figure 1-B). The total leaf area per plant increased up to $658 \%$ at $\mathrm{P} 0,157 \%$ at $\mathrm{P} 30,24 \%$ at $\mathrm{P} 90$ and $21 \%$ at $\mathrm{P} 270$ due to mycorrhizal symbioses (Figure 2-A), while the leaf area per leaf increased up to $144 \%$ in the soil without $\mathrm{P}$ addition (P0), $14 \%$ at $\mathrm{P} 30,12 \%$ at P90 and 20\% at P270 (Figure 2-B).
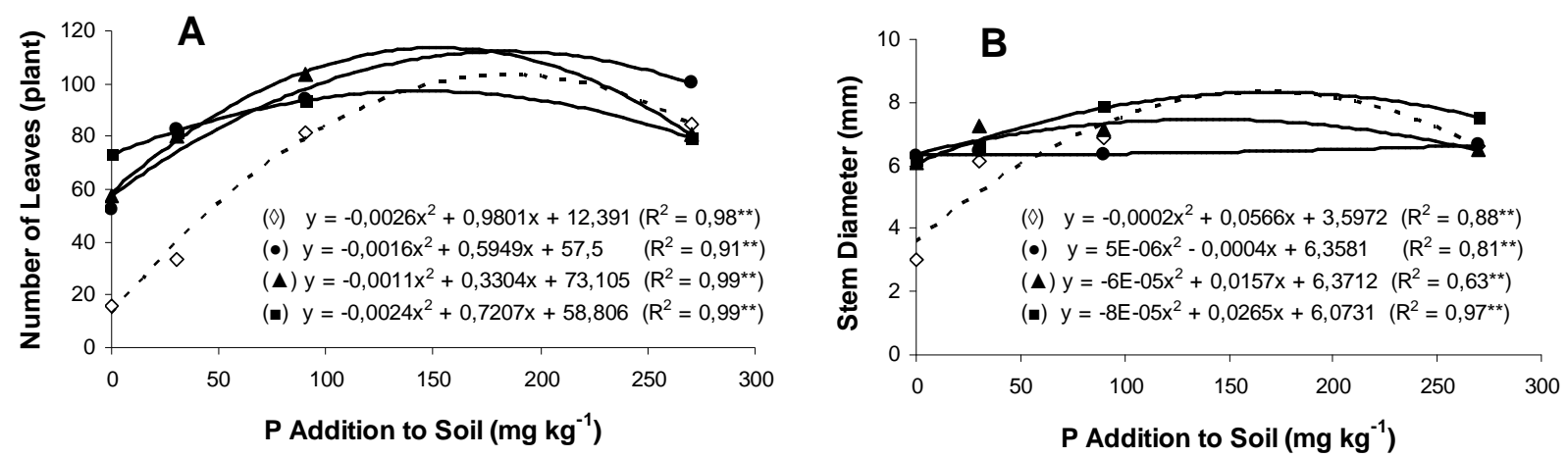

Figure 1 - Number of leaves (A) and stem diameter (B) of acerola due to arbuscular mycorrhizal fungi with different P levels. $(\diamond)$ Control; $(\bullet)$ G.margarita; $(\boldsymbol{\Delta})$ G. manihotis and (a) G. clarum.* and ** Significant at 5 and $1 \%$ of probability, respectively, by $\mathrm{F}$ test.
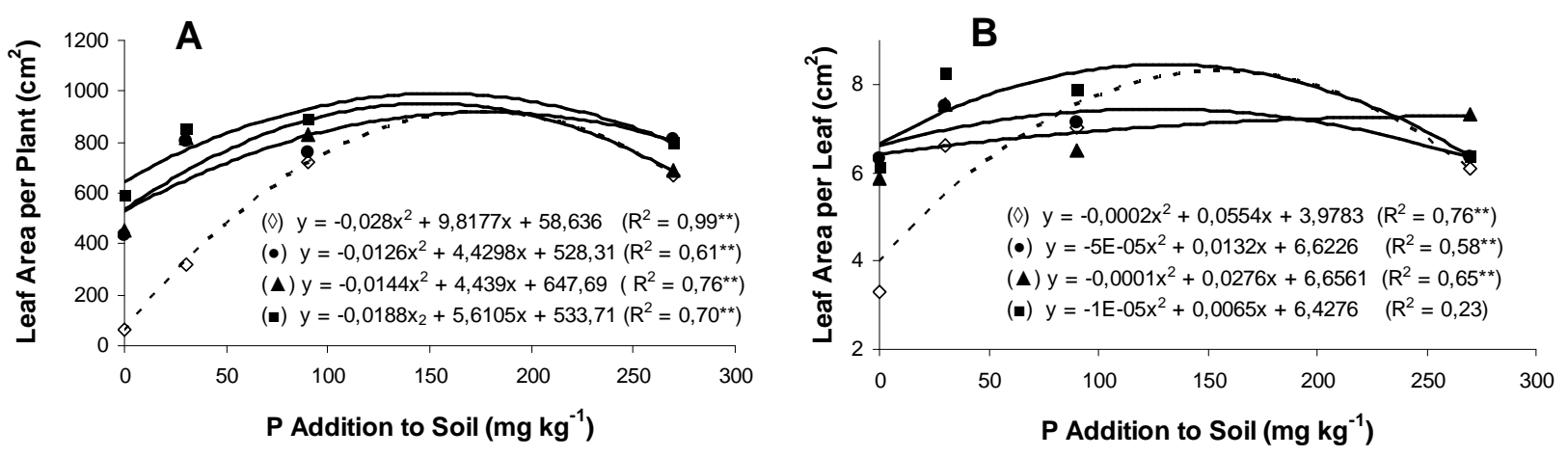

Figure 2 - Total leaf area per plant (A) and leaf area per leaf (B) of acerola due to arbuscular mycorrhizal fungi under different P levels. $(\diamond)$ Control; $(\bullet)$ G.margarita; $(\boldsymbol{\Delta}) G$. manihotis and (@) G. clarum. * and ** Significant at 5 and $1 \%$ of probability, respectively, by $\mathrm{F}$ test. 
The quadratic model due to increasing $\mathrm{P}$ doses has been observed frequently in the mycorrhizal plants (Saggin Júnior and Siqueira, 1996; Rocha et al., 2006; Freitas et al., 2006), providing evidence that the most mycorrhizal benefits occur mainly under lower levels of P. However, we also observed the quadratic regression model to non-mycorrhizal plants. On the other hand, Corrêa et al. (2002a) observed a linear regression model in nonmycorrhizal plants, due to the addition of up to $450 \mathrm{mg} \mathrm{kg}^{-1}$ of $\mathrm{P}$ in the number of leaves per plant and the diameter of the stem.

There was an accentuated increase in the development of the plant at low levels of $\mathrm{P}$ in both mycorrhizal and non-mycorrhizal plants. The maximum total leaf area was obtained at 150 to $180 \mathrm{mg} \mathrm{kg}^{-1}$ of $\mathrm{P}$ and it started to decrease at higher $\mathrm{P}$ levels. The efficiency of mycorrhizal symbiosis could be seen by calculating the $\mathrm{P}$ dose necessary for production of $80 \%$ of the maximum leaf area per plant. G. clarum produced $80 \%$ of the maximum leaf area per plant with an addition of $40 \mathrm{mg} \mathrm{kg}^{-1}$ of $\mathrm{P}$, whereas in non-mycorrhizal plants that total leaf area per plant development required the addition of a 2.8 -fold higher dose $\left(110 \mathrm{mg} \mathrm{kg}^{-1}\right.$ of P). Total leaf area per plant is considered an index of the growth parameter because it is highly dependent on the photosynthetic capacity.

In general, mycorrhizal symbioses improved all the growth parameters in terms of total leaf area per plant and leaf area per leaf (leaf size), indicating that the plant vegetative growth in particular and the total functional photosynthetic surface area improved due to AMF. Therefore, the greater extent of development could be attributed to enhanced inorganic nutrition absorption and higher rates of photosynthesis. Mycorrhizal plants often showed higher photosynthetic rates than do non-mycorrhizal plants (Augé, 2001) as confirmed by Machineski (2008) in the castor bean, in which the AMF increased the photosynthetic rate by $150 \%$ at low levels of soil P. It is known that both $\mathrm{P}$ addition and AMF could promote the plant growth by increasing the leaf area per unit of plant biomass (leaf area radio, LAR) (Bass and Lambers, 1988), which contributes to an increase in the $\mathrm{C}$ assimilation on a whole-plant basis (Lambers and Poorter, 1992).

The mycorrhizal plant accumulates higher amounts of $\mathrm{P}$ in the shoot and the root than do the non-mycorrhizal plants. The AMF provided an increase in the accumulation of $\mathrm{P}$ in the shoot up to $1892 \%$ at $\mathrm{P} 0,328 \%$ at $\mathrm{P} 30,156 \%$ at $\mathrm{P} 90$ and $75 \%$ at $\mathrm{P} 270$ due to mycorrhizal symbioses (Figure 3-A), while the increase in the root was up to $2800 \%$ under the soil without $\mathrm{P}$ addition (P0), $235 \%$ at $\mathrm{P} 30,146 \%$ at $\mathrm{P} 90$ and $182 \%$ at $\mathrm{P} 270$ (Figure 3-B).
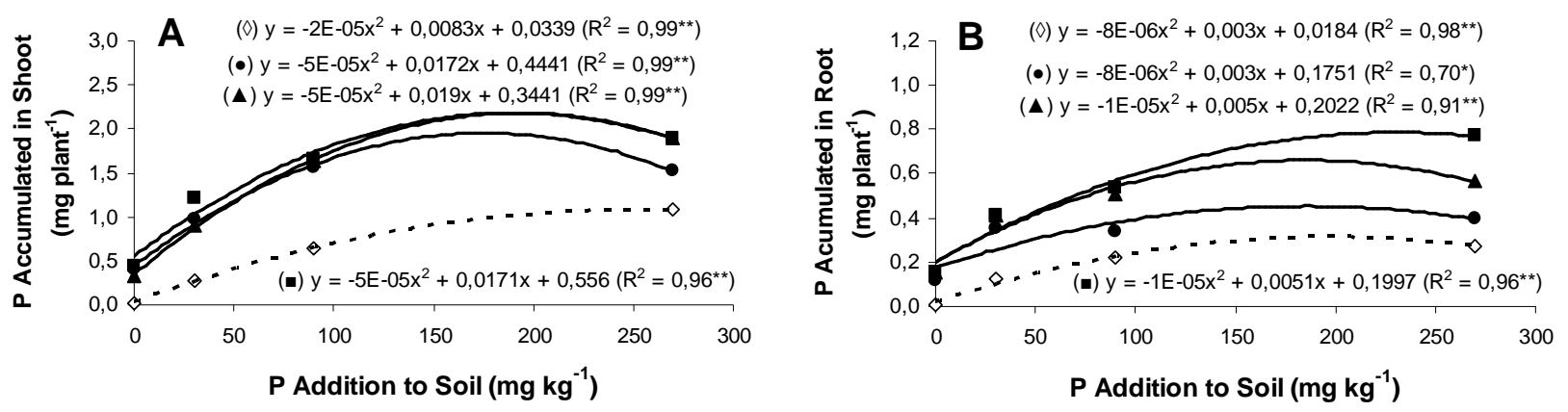

Figure 3 - P accumulated in shoot (A) and root (B) of acerola due to arbuscular mycorrhizal fungi under different P levels. $(\diamond)$ Control; $(\bullet)$ G. margarita; $(\boldsymbol{\Delta})$ G. manihotis and $(\boldsymbol{\square}) G$. clarum. $*$ and $* *$ Significant at 5 and $1 \%$ of probability, respectively, by $\mathrm{F}$ test.

The benefit of the mycorrhizal effect even in the soils with high levels of $\mathrm{P}$ provides evidence that AMF can contribute efficiently to $\mathrm{P}$ absorption and its transportation in the plant. The increase in the $\mathrm{P}$ capacity of the plants can be attributed to the large increase in soil exploration area (more than one hundred times) due to mycorrhizal external mycelium production, its greater efficiency of nutrient absorption and higher affinity (lower $\mathrm{Km}$ ) for $\mathrm{P}$ uptake from the soil solution with low $\mathrm{P}$ concentration compared to normal plant roots. For example, the rate of $\mathrm{P}$ inflow into mycorrhizal roots was much higher (almost five times superior) than that of non-mycorrhizal plants (Smith and 
Read, 1997; Bolan, 1991). This higher efficiency of $\mathrm{P}$ uptake by the mycorrhizal hyphae is important because mycorrhizal plants access the same forms of available $\mathrm{P}$ than the nonmycorrhizal plants (Bolan, 1991).

In the present study, accentuated differences in plant development were not observed due to the inoculation of different species of AMF. However, functional differences have been recognized among the AMF species. This varying effect of AMF species is due to their capacity to infect and colonize the roots and to the capacity of the mycelium to spread through the soil and to benefit the host plant. These differences are due to the shift in the balance between the nutritional benefit to the plant provided by the mycorrhizae and the cost of the plant photoassimilates required for the mycorrhizal maintenance (Saggin Júnior and Siqueira, 1996). However, there are other factors that influence the $\mathrm{P}$ uptake, such as arbuscules efficiency (interface between vegetable and fungal cell) extension, viability and transport capacity by fungal mycelium, as well as the number of root hairs, the transport and the use of $\mathrm{P}$, growth rate and the nutritional demand of the plant (Smith and Read, 1997). Therefore, the variation of mycorrhizal efficiency is determined not only by the plant host and mycorrhizal genotypes but also by the environmental conditions (Zangaro et al., 2007).

The higher increase of $\mathrm{P}$ uptake by the mycorrhizal plants resulted from the greater amount of root-external hyphae, which spread up to $12 \mathrm{~cm}$ throughout the rhizosphere soil (Smith and Read, 1997) for accessing and absorbing the soil nutrients located beyond the $\mathrm{P}$ depletion zone around the roots. This nutrient depletion zone develops when nutrients are removed from the soil solution more rapidly than they can be replaced by the diffusion. In addition, mycorrhizal hyphae are able to take up P more efficiently and transport it over longer distances than the plant root system (Smith and Read, 1997; Sylvia, 1998). Another factor which contributes to the effective absorption of nutrients by mycorrhizae hyphae is their narrow diameter $(2-15 \mu \mathrm{m})$ relative to the roots. The steepness of the diffusion gradient for a nutrient is inversely related to the radius of the absorbing unit. Therefore, the soil solution should be less depleted at the surface of a narrow absorption unit such as hyphae. Furthermore, narrow hyphae can grow into small soil pores inaccessible to the roots or even to the root hairs (Sylvia, 1998; Jakobsen,
1999). In tropical conditions, about 47 meters of total fungi mycelium per gram of soil were observed in bauxite mining area under rehabilitation (Melloni et al., 2003). Thus, the root colonization does not express the mycorrhizal benefit to the plant directly because it does not reflect the capacity of extra-radical mycelium.

The manganese $(\mathrm{Mn})$ content increased in the acerola shoots due to $\mathrm{P}$ levels (Figure 4) as observed by Corrêa et al. (2002b), wherein the Mn content increased due to the addition of up to 450 mg kg-1 of P. However, in the present work, all the mycorrhizal plants presented lower $\mathrm{Mn}$ concentration than the non-mycorrhizal plants. The higher $\mathrm{Mn}$ decrease was provided by $\mathrm{G}$ clarum, followed by G. manihotis and G. margarita. These results indicated that G. clarum had the greatest efficiency in promoting plant protection against an eventual excess of $\mathrm{Mn}$ in the acidic soil. The decrease of Mn content due to AMF has been observed previously in soybean and castor bean plants. The study in soybeans showed that mycorrhizal plants showed a decrease in $\mathrm{Mn}$ content of up to $48 \%$ in the shoots and about $51 \%$ in the roots (Nogueira, 1999; Nogueira and Cardoso, 2003). These decreases were similar to those observed in castor bean mycorrhizal plants (Machineski, 2008).

The mechanisms responsible for $\mathrm{Mn}$ toxicity attenuation in mycorrhizal plants are not entirely known; however, as suggested by Nogueira and Cardoso et al., (2003), the alleviation of $\mathrm{Mn}$ toxicity in the mycorrhizal plants is not due exclusively to the AMF but is also a result of the changes in host physiology, which reflect the microbial community and the biological processes of $\mathrm{Mn}$ oxidation and reduction reactions. It has been suggested, however, that some results prove that manganese can be retained in AMF mycelium hyphae in order to be complexed by polyphosphate granules in the mycelium fungi or oxidized in the plant roots (Smith and Read, 1997; Cardoso et al. 2003). However, in another study with soybean, no effect of mycorrhizae on Mn oxidation in the root was detected (Cardoso et al., 2003). According to Mukhopadhyay and Sharma (1991) the Mn toxicity alleviation in mycorrhizal plants may be attributed to an indirect effect of higher $P$ content in shoots, which forms the complexes with $\mathrm{Mn}$ in the plant, thus reducing its activity.

The mycorrhizal effectiveness (ME) value measured how much the growth of the mycorrhizal plant was improved compared to the non- 
mycorrhizal plants. When the ME was based on the total leaf area per plant variable, the mycorrhizal plants presented higher ME under low $\mathrm{P}$ levels (Figure 5). The ME observed under P0 (6.8 $\mathrm{mg} \mathrm{kg}^{-1}$ of P) was $569 \%$ for G. margarita, $599 \%$ for G. manihotis and $811 \%$ for G. clarum. Under P30 (18.6 mg kg-1 of P) the ME decreased approximately four fold, whereas at P270 (116 mg kg $\mathrm{mg}^{-1}$ of $)$ the ME decreased to almost zero with $G$. manihotis inoculation and around $20 \%$ for the other two AMF species. However, in addition to the variation due to the species used, the ME can vary depending on the variable considered.

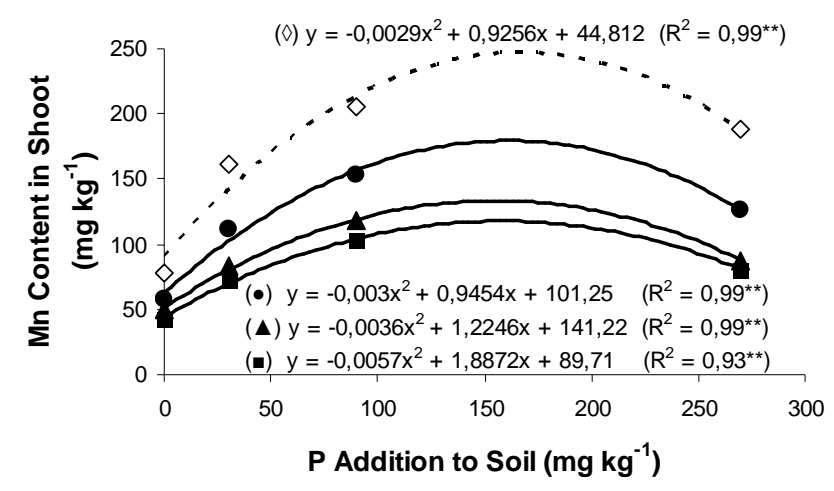

Figure 4 - Manganese content in acerola shoots due to arbuscular mycorrhizal fungi under

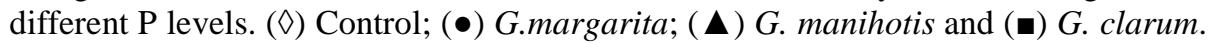
$*$ and $* *$ Significant at 5 and $1 \%$ of probability, respectively, by $\mathrm{F}$ test.

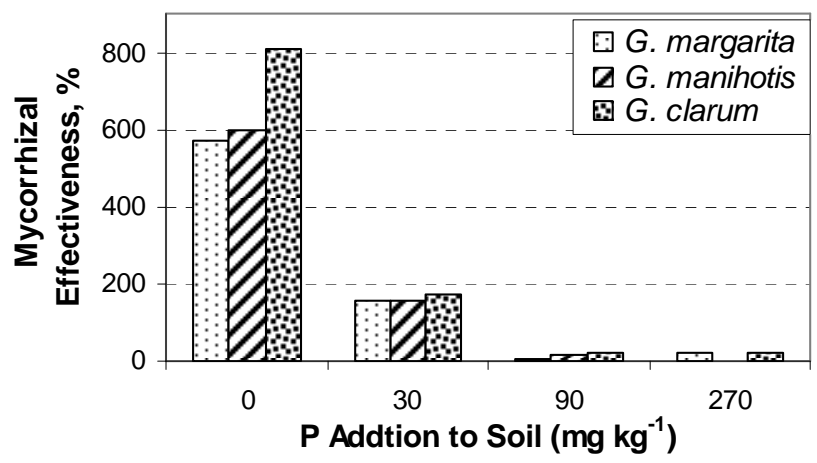

Figure 5 - Mycorrhizal effectiveness. ME = (total leaf area of mycorrhizal plant - total leaf area of non-mycorrhizal plant) / (total leaf area of non-mycorrhizal plant) x 100.

The large difference in ME magnitude due to AMF species depend on the considered variable, as has been mentioned previously in the literature. However, certain AMF species presented high efficiency in one variable, while other species presented efficiency in another variable. It should be noted that the results can be specific for the soil conditions studied. The highest mycorrhizal efficiency was observed in the low P levels, which demonstrated that the plants in sub-optimal $\mathrm{P}$ conditions received the maximum mycorrhizal benefit.
The results showed the unquestionable benefits of the mycorrhizal associations to the acerola seedlings, which should not be ignored in any program of acerola seedlings production, especially those which utilized sterile substrate. Therefore, mycorrhizal inoculation is a practice that should be considered in the nursery phase because it may contribute to better development, nutrition and transplant survival in the field even in the soils with low $\mathrm{P}$ concentration. 


\section{ACKNOWLEDGEMENTS}

We thank Dr. Marcos Antonio Pavan for his critical reading of this manuscript.

\section{REFERENCES}

Augé, R.M. (2001), Water relations, drought and vesicular-arbuscular mycorrhizal symbiosis. Mycorrhiza, 11: 3-42.

Balota, E.L.; Lopes, E.S.; Hungria, M.; Dobereiner, J. (1997), Inoculação de bactérias diazotróficas e fungos micorrízicos arbusculares na cultura da mandioca. Pesq. agropec. bras., 32: 627-639.

Bass, R.; Lambers, H. (1988), Effects of vesiculararbuscular mycorrhizal infection and phosphate on Plantago major ssp. pleiosperma in relation to the internal phosphate concentration. Phys. Plantarum, 74: 701-707.

Bhering, S.B.; Santos, H.G. Mapa de solos do estado do Paraná: Legenda atualizada. Rio de Janeiro: Embrapa Florestas: Embrapa Solos: Instituto Agronômico do Paraná, 2008. 74p.

Bolan, N.S. (1991), A critical review on the role of mycorrhizal fungi in the uptake of phosphorus by plants. Plant Soil, 134: 189-207.

Cardoso, E.J.B.N.; Navarro, R.B.; Nogueira, M.A. (2003), Absorção e translocação de manganês por plantas de soja micorrizadas, sob doses crescentes deste nutriente. R. Bras. Ci. Solo, 27: 415-423.

Chu, E.Y. (1993), Inoculação de fungos micorrízicos arbusculares em plântulas de acerola (Malpighia glabra L.). Belém: Embrapa-CPATU. 15 p. (Embrapa-CPATU. Boletim de Pesquisa, 149).

Corrêa, F.L.O.; Souza, C.A.S.; Carvalho, J.G.; Mendonça, V. (2002a), Fósforo e zinco no desenvolvimento de mudas de aceroleira. Rev. Bras. Frutic., 24: 793-796.

Corrêa, F.L.O.; Souza, C.A.S.; Mendonça, V; Carvalho, J.G. (2002b), Acúmulo de nutrientes em mudas de aceroleira adubadas com fósforo e zinco. Rev. Bras. Frutic., 24: 765-769.

Costa, C.M.C.; Maia, L.C.; Cavalcante, U.M.T.; Nogueira, R.J.M.C. (2001), Influência de fungos micorrízicos arbusculares sobre o crescimento de dois genótipos de aceroleira (Malpighia emarginata D.C.). Pesq. agropec. bras., 36: 893-901.

Costa, C. M. C.; Cavalcante, U. M. T.; Goto, B. T.; Santos, V. F.; Maia, L. C. (2005). Fungos micorrízicos arbusculares e adubação fosfatada em mudas de mangabeira. Pesq. agropec. bras., 40: 225232.
Freitas, M.S.M.; Martins, M.A.; Carvalho, A.J.C. (2006). Crescimento e composição da menta em resposta à inoculação com fungos micorrízicos arbusculares e adubação fosfatada. Hortic. Bras., 24: 11-16.

Gonzaga Neto, L.; Soares. J.M. (1994), Acerola para exportação: aspectos técnicos da produção. Brasília: Embrapa-SPI/FRUPEX. 43p. (Série Publicações Técnicas, 10).

Jakobsen, I. (1999), Transport of phosphorus and carbon in arbuscular mycorrhizas. In: Varma, A.; Hock, B. (Eds.), Mycorrhiza: structure, function, molecular biology and biotechnology, $2^{\text {nd }}$ Ed. Springer-Verlag Berlin Heidelberg. p.305-332.

Lambers, H.; Poorter, H. (1992), inherent variation in growth rate between higher plants: a search for physiological causes and ecological consequences. Adv. Bot. Res., 23: 187-261.

Machineski, O. (2008), Resposta da mamoneira a fungos micorrízicos arbusculares e a doses de fósforo. Dissertação de Mestrado, Universidade Estadual de Londrina. 51p.

Marschner H.; Dell, B. (1994), Nutrient uptake in mycorrhizal symbiosis. Plant Soil, 159: 89-102.

Melloni, R.; Siqueira, J.O.; Moreira, F.M.S. (2003), Fungos micorrizicos em solos de área de mineração de bauxita em reabilitação. Pesq. agropec. bras., 38: 267-276.

Mukhopadhyay, M.J.; Sharma, A. (1991), Manganese in cell metabolism of higher plants. Bot. Rev., 57: 117-149.

Nogueira, M.A.; Cardoso, E.J.B.N. (2003), Mycorrhizal effectiveness and manganese toxicity in soybean as affected by soil type and endophyte. Sci. Agric., 60: 329-335.

Nogueira, M.A.; Cardoso, E.J.B.N. (2007), Phosphorus availability changes the internal and external endomycorrhizal colonization and effects symbiotic effectiveness. Sci. Agric., 64: 295-300.

Nogueira. M.A. (1999), Interações entre micorriza, rizobactérias, fósforo e silício na manifestação da toxidez de manganês em soja. Tese de Doutorado, ESALQ/USP. 195p.

Pavan, M.A.; Bloch, M.F.; Zemplski, H.C.; Miyazawa, M.; Zocoler, D.C. (1992), Manual de análise química de solo e controle de qualidade. (Circular técnica 76) IAPAR, Londrina. 46p.

Rocha, F. S.; Saggin Junior, O.; Silva, E. M. R.; Lima, W. L. (2006), Dependência e resposta de mudas de cedro a fungos micorrízicos arbusculares. Pesq. agropec. bras., Brasília, 41: 77-84.

Saggin Junior, O.J.; Siqueira, J.O. (1996), Micorrizas arbusculares em cafeeiro. In: SIQUEIRA, J.O. (Ed.) Avanços em fundamentos e aplicação de micorrizas. Lavras: UFLA: DCS: DCF. 1996. p.203-254. 
SAS. (2002), SAS/STAT User's guide: statistics. $9^{\text {th }}$ ed. Cary, NC, USA. SAS Institute.

Smith, S.E.; Read, D.J. (1997), Mycorrhizal Symbiosis. Academic Press, Inc. p.605.

Sylvia, D.M. (1998), Mycorrhizal Symbioses. In: D.M. Sylvia; J.J. Fuhrmann; P.G. Hartel; D.A. Zuberer, Prentice-Hall, Inc. p.408-426.
Zangaro, W.; Nishidate, F.R.; Vandresen, J.; Andrade, G.; Nogueira, M.A. (2007). Root mycorrhizal colonization and plant responsiveness are related to root plasticity soil fertility and successional status of native woody species in southern Brazil. J. Trop. Ecol., 23: 53-62.

Received: May 26, 2009; Revised: September 12, 2010; Accepted: January 18, 2011. 